Viktor Potočnik

\title{
VLOGA ZDRUŽENEGA BOJEVANJA RODOV V OKOLJU HIBRIDNEGA VOJSKOVANJA V KONTEKSTU TRENUTNEGA STANJA IN RAZVOJNIH MOŽNOSTI SV
}

\author{
ROLE OF COMBINED ARMS WARFARE \\ IN HYBRID WARFARE ENVIRONMENT \\ IN THE CONTEXT OF SAF'S CURRENT SITUATION \\ AND DEVELOPMENTAL OPPORTUNITIES
}

Povzetek Prispevek se ukvarja z vprašanjem sodobnega vojskovanja. Narava vojne se v času ne spreminja, spreminjajo pa se oblike in metode, $s$ katerimi se vojne vodijo. V zadnjem času je moderno govoriti o hibridnem vojskovanju, kako ga kdo pojmuje, pa je zelo različno in odvisno od avtorjev. Članek poskuša pokazati, da pod pojmom hibridnega vojskovanja ne najdemo velikih revolucionarnih sprememb v oblikah in metodah vojskovanja in da je za zmago v sodobnem spopadu še vedno zelo relevanten koncept združenega bojevanja rodov, ki pa ga je treba razumeti v okviru sodobnega vojskovališča, katerega glavni značilnosti sta boj v informacijskem prostoru in »hibridnost«. Članek podrobneje pogleda tudi na strukturo enot taktične ravni SV, in sicer z vidika združenega bojevanja rodov in delovanja na hibridnem vojskovališču.

Ključne Slovenska vojska, združeno bojevanje rodov, hibridno vojskovanje, brigada, besede polk/bataljon.

Abstract The article deals with the problems of modern warfare. The nature of war does not change through time; what changes is the ways and methods of conducting it. Lately, it has been popular to talk about hybrid warfare, but its perceptions vary significantly according to authors. The aim of the article is to show that the term hybrid warfare does not bring anything revolutionary to the ways and methods of warfare and that today, the concept of combined arms is still very relevant for winning a contemporary conflict. However, it has to be perceived from the perspective of a contemporary battlefield whose main characteristics are cyber warfare and its hybrid nature. The article also discusses in detail the structure of the Slovenian Armed Forces' tactical level in terms of combined arms and »hybrid« warfare.

Key words Slovenian Armed Forces, combined arms warfare, hybrid warfare, brigade, regiment/battalion. 
Uvod Ameriški general McMaster je opredelil »/.../ štiri nespremenljive karakteristike vojne (McMaster, 2015, str. 7-10). Prvič, vojna je politična: je samo del širšega koncepta, s katerim je mogoče doseči uspeh v konfliktu med igralci na mednarodni politični sceni. Vojne ni mogoče ločiti od njene politične narave in izogibati se je treba teorijam, ki obljubljajo hitre, nezapletene in poceni zmage, temelječe na premoči v tehnologiji. Drugič, vojna je človeška: ljudje se še vedno vojskujejo zaradi enakih vzrokov kot pred 2500 leti - strahu, časti in interesa. Tretjič, vojna je negotova: načrti ne morejo narekovati poteka dogodkov in napredek v vojni ni linearen ali predvidljiv. Četrtič, vojna je spopad volj: edini cilj v vojni mora biti zmaga, vse drugo je kontraproduktivno in nepotrebno. Zmaga pa pomeni (racionalno) odločnost, da dosežeš vzdržljiv rezultat, običajno politični, ki ustreza tvojim vitalnim interesom, in ne nujno brezpogojne predaje ali dviga kakršne koli omejitve na količino uporabljene sile. Kot bi dejal Clausewitz, je zmaga dosežena, ko je sovražnik prepričan, da je premagan.«

Z njimi je namreč želel poudariti nespremenljivo naravo vojne. Vojne se danes vodijo z najrazličnejšimi tehnologijami in na najrazličnejše načine, toda noben izmed njih, pa naj se nam zdi še tako nov, sam po sebi ne spreminja narave vojne, ki je politični, človeški in negotov spopad volj.

Če torej sprejmemo, da je narava vojne nespremenljiva, pa se moramo hkrati zavedati, da se zelo spreminjajo načini in koncepti vodenja vojn. Na načine in koncepte vodenja vojn pa ne vplivajo le spremembe $\mathrm{v}$ tehnologiji, temveč tudi spremembe v družbenih odnosih. Med temi koncepti je tudi združeno bojevanje rodov. Članek pred vami bo predvsem poskušal pogledati, ali ima koncept združenega bojevanja rodov (ZBR) še relevantno vlogo $\mathrm{v}$ sodobnem vojskovanju in kaj ta pojem na sodobnem vojskovališču sploh skriva.

Da bi lahko to bolje razumeli, bo najprej treba pogledati, kaj se pravzaprav skriva za pojmom združenega bojevanja rodov in kakšne so temeljne značilnosti sodobnega vojskovanja, ki ga bomo za ta članek imenovali hibridno vojskovanje. Opredelili bomo tudi vlogo in naloge združenega bojevanja rodov v vojskovanju te vrste in nazadnje skušali ugotoviti, kje na tem področju je Slovenska vojska.

\section{HIBRIDNO VOJSKOVANJE}

Pred nadaljnjo obravnavo združenega bojevanja rodov se moramo nujno vprašati, s kakšnim sovražnikom so danes oborožene sile sploh soočene in seveda, ali je za spopad s takšnim sovražnikom koncept združenega bojevanja rodov primeren. Vztrajanje na konceptu bojevanja, ki ne omogoča ustreznega odziva na grožnjo, je namreč nesmiselno.

Zavezniška doktrina ne pozna pojma hibridna grožnja ali hibridno vojskovanje, pozna pa pojem asimetrične grožnje, ki je »/.../ grožnja, ki izhaja iz morebitne uporabe različnih sredstev ali metod $\mathrm{z}$ namenom preslepiti ali izničiti sovražnikovo moč, 
pri čemer izkorišča njegove slabosti za doseganje neproporcionalno pomembnega rezultata. ${ }^{1}$ (AAP-06, 2013, str. 2-A-20)

Doktrina vojske ZDA pozna pojem hibridne grožnje. »Hibridna grožnja je raznolika in dinamična kombinacija regularnih sil, neregularnih sil, teroristov, kriminalnih elementov ali kombinacija le-teh, vseh sodelujočih, da bi dosegli skupne koristne učinke.« Kot nadalje pravi njihova doktrina, »/.../ vojska ZDA izvaja vojskovanje tako proti konvencionalnim kot hibridnim grožnjam. $\aleph^{2}$ (ADP 3-0, 2011, str. 4, 5)

Brigadir Škerbinc ugotavlja da /.../ hibridno vojskovanje združuje in ustvarja sinergijske učinke materialnih in kognitivnih zmogljivosti oziroma konvencionalnih in nekonvencionalnih zmogljivosti ter odkrito ali prikrito agresivno, brez upoštevanja legalnih omejitev, ob simultani uporabi vseh elementov nacionalne moči vsiljuje svojo voljo sovražnikom pri doseganju svojih mednarodno nelegitimnih strateških ciljev. Zanj naj bi bili značilni hkratna uporaba konvencionalnih, specialnih in neregularnih sil ter plačancev, intenzivna uporaba propagande, psihološke operacije in zavajanje, agresivni ekonomski pritiski, ustvarjanje in uporaba petokolonašev ter ofenzivno kibernetsko delovanje. (Škerbinc, RO maj 2015, str. 26)

Puyvelde ugotavlja, da se vseh 28 članic Natovega zavezništva ne more poenotiti o tem, kaj sta hibridna grožnja in hibridno vojskovanje, in da je potemtakem tudi nemogoče oblikovati jasno strategijo spopadanja s hibridno grožnjo (Puyvelde, 2015, str. 3). Nasprotno meni, da je uporaba termina hibridno celo nevarna, saj implicira neko novo obliko grožnje oziroma vojskovanja, v resnici pa ne gre za nič novega. Termin ima torej po njegovem samo opisno vrednost v tem, da $\mathrm{z}$ enim izrazom poimenujemo kombinacijo konvencionalnih in nekonvencionalnih groženj in sovražnikov (Puyvelde, 2015, str. 2).

Schadlow ugotavlja, da se pojem hibridno vojskovanje nanaša na sredstva vojskovanja, ne pa na načela, cilje ali samo naravo vojne (Schadlow, 2015, str. 3). Da torej ne gre za nič drugega, kot za kompleksno mešanico že znanih in poznanih oblik vojskovanja, ki v naravo vojne ne vnašajo nič revolucionarno novega. Ugotavlja pa, da ima zavezništvo (Nato) s tem precej velike težave, ker vidi posamezne elemente hibridnega vojskovanja ločeno, kot nekakšne osamljene incidente, ne zmore ali noče pa videti vseh povezav in tako celotne grožnje (Schadlow, 2015, str 1-3).

Po drugi strani ruska vojaška doktrina svoje značilne akcije opredeljuje s souporabo preciznega, elektromagnetnega, laserskega in infrazvočnega orožja, z računalniškimi sistemi, vozili brez posadke in robotizirano opremo. (Ruska vojaška doktrina, 2010, t. 15)

\footnotetext{
A threat emanating from the potential use of dissimilar means or methods to circumvent or negate an opponent's strengths while exploiting his weaknesses to obtain a disproportionate result.

2 A hybrid threat is the diverse and dynamic combination of regular forces, irregular forces, terrorist forces, criminal elements, or a combination of these forces and elements all unified to achieve mutually benefitting effects... Army forces conduct regular and irregular warfare against both conventional and hybrid threats.
} 
Pojem hibridnega vojskovanja torej ne prinaša nič pretresljivo novega. Sodobno vojskovanje ostaja, kot je vedno bilo. Temeljne značilnosti vojne se s prihodom informacijske dobe niso spremenile, kot ugotavlja že McMaster (v uvodu). So se pa spremenile razsežnosti vojskovanja, ki bolj kot kdaj koli vključuje vse pore družbenega življenja.

Oborožene sile morajo biti danes pripravljene na sovražnika, ki akcij ne bo izvajal le $\mathrm{v}$ vojaškem spektru, temveč tudi v informacijsko/kibernetskem prostoru, z uporabo psiholoških in ekonomskih operacij itn.

V nadaljevanju pa bomo skušali pogledati, kakšna je vloga koncepta združenega bojevanja rodov v spopadu s takšnim sovražnikom, ki ga bomo v članku imenovali hibridni, a ob jasnem zavedanju, da ne gre za nekaj novega, temveč za kombinacijo različnih groženj, ki so na različne načine povezane in zato izjemno zapletene.

\section{ZDRUŽENO BOJEVANJE RODOV}

Zavezniška doktrina pozna pojma combined arms (AJP-3.2., 2009, Lexicon-6) ${ }^{3}$ in

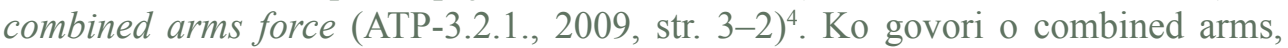
govori o združevanju več rodov, kot so pehota, oklep, artilerija in letalstvo, ko pa govori o combined arms force (slov. bojna skupina), govori o združevanju več rodov, ki jih podpira ustrezen element zagotovitve bojnega delovanja. Bojna skupina naj bi predstavljala uravnoteženo silo komplementarnih zmogljivosti, v kateri različne zmogljivosti premagujejo omejitve druga druge.

Vojaška doktrina Slovenske vojske govori o bojnih skupinah kot o temeljnem pristopu k organiziranju za bojno delovanje, pri katerem se glede na poslanstvo združujejo enote rodov v četne, bataljonske in brigadne bojne skupine. To združevanje povzroča učinke, ki se medsebojno dopolnjujejo ali krepijo. Bistvo uveljavljanja tega načina organiziranja sil je učinkovita usklajenost vseh bojnih funkcij. Vsak del ima sicer drugačen namen, vendar je namera oblikovati usklajen učinek proti sovražniku (VD, 2006, str. 28). Vojaška doktrina govori tudi o tem, da je za uresničitev cilja bojnega delovanja sil Slovenske vojske pri izvajanju vojaške obrambe Republike Slovenije »/.../ nujno vzpostaviti učinkovito sodelovanje sosednjih enot, enot različnih rodov in služb, enot zavezništva in nosilcev civilnih zmogljivosti.«(VD, 2006. str. 66)

\footnotetext{
AJP-3.2, Lexicon-6 Combined arms; Application of several arms, such as infantry, armour, artillery and aviation.

4 ATP-3.2.1, str.3-2 A combined arms force is the grouping and application of several arms such as infantry, armour, engineer, artillery and aviation, supported by an appropriate combat service support element. They provide and balanced mix of complementary capabilities and help offset the limitations of their constituent parts. They may be fixed groups or ad hoc that come together for specific tasks and operations and then redeploy to their parent organisations upon task completion.
} 
Doktrina vojske ZDA pozna pojem combined arms maneuver ${ }^{5}$ kot aplikacijo elementov bojne moči v enotni akciji, da bi se premagale sovražnikove kopenske sile in dosegle fizična, začasna in psihološka prevlada nad sovražnikom ter prevzela in izkoristila pobuda (ADP 3-0, 2011, str. 6). Pod pojmom combined arms warfare ${ }^{6}$ pa razume široko uporabo zelo natančne in ubojne oborožitve, visoko stopnjo taktične mobilnosti, dinamično naravo, hitro spreminjanje situacije in velik prostorski obseg območij delovanja enot (ADP 3-90, 2012, str. 10). Posamezniki, skupine, oddelki in enote se morajo vsi usposabljati kot del združenega bojevanja rodov. (ADP 7-0, 2012, str. 2)

Doktrina oboroženih sil Velike Britanije govori o tako imenovanih combined arms groupings, ki združujejo več rodov (pehota, oklep, letalstvo, artilerijo in inženirce), da bi hkrati izrabili in povečali njihovo bojno moč. Med temi oblikami je tudi bojna skupina, ki združuje več rodov na temelju poveljstva, oklepne, izvidniške, pehotne ali letalske enote in je oblikovana za opravljanje širokega spektra taktičnih nalog. Pri tem pa mora biti oblikovana tako, da hkrati lahko izpolnjuje štiri naloge. Zagotoviti mora zaščitne sile, ki sovražnika poiščejo, pridobijo informacije in ga vežejo, manevrske sile, ki odločilno delujejo na sovražnika, sile za izrabo uspeha in rezervo (ADP, 2010, str. 4-6).

Oborožene sile Ruske federacije so zgrajene na tradiciji vojaške misli Sovjetske zveze, ki je v obdobju pred drugo svetovno vojno razvila koncept tako imenovane globoke bitke (angl. Deep battle). Gre za koncept združenega bojevanja rodov, ki je nastal kot odgovor na povečane zmogljivosti sistemov ognjene podpore (artilerije in letalstva) ter pojav mehaniziranih in zračnodesantnih sil. S pojavom teh sil in njihovih zmogljivosti je namreč postal nevaren tudi sovražnik, lociran več kilometrov za prednjo črto stika, ki ga je bilo treba napasti z enako odločnostjo kot sovražnika v neposrednem stiku. Tako so ugotovili, da je zaradi nevarnosti po globini kot tudi potenciala lastnih sil za ogenj in manever po tej globini nujno združeno bojevanje rodov (FM 100-2-1,1984, str. 2-6).

Koncept je temeljil na hkratnem delovanju artilerije in letalstva po celotni globini sovražnikove obrambe, hkrati z napadom tankov in pehote, ki bi prebili sovražnikovo obrambo na taktični ravni in nato hitro ter odločno prodrli v globino operativnega območja. Temu bi sledilo uničenje sovražnikovih komunikacijskih linij ter centrov poveljevanja in kontrole (v nadaljevanju PINK), zaradi česar bi prišlo do razpada preostanka sovražnikovih obrambnih linij. To je zahtevalo visoko stopnjo usklajevanja in nadzora različnih rodov pod enotnim poveljstvom, tako na stopnji načrtovanja kot izvedbe bojnih aktivnosti (FM 100-2-1,1984, str. 2-6).

\footnotetext{
5 "Combined arms maneuver is the application of the elements of combat power in unified action to defeat enemy ground forces; to seize, occupy, and defend land areas; and to achieve physical, temporal, and psychological advantages over the enemy to seize and exploit the initiative..."

6 "Combined arms warfare is characterized by the widespread application of highly accurate and lethal weapons, a high degree of tactical mobility, a dynamic nature, rapid situational changes, and the large spatial scope of unit areas of operations."
} 
Po koncu hladne vojne je prišlo v Rusiji na vojaškem področju do velikih sprememb. Dejstvo pa je, da Rusi niso mirovali. Med vojnami v Zakavkazju in z Gruzijo leta 2008 so pridobili kar nekaj izkušenj. Te so pokazale na velike pomanjkljivosti ruske vojske na področjih informacijske tehnologije in doktrine (Thomas v Blank \& Weitz, 2010, str. 265). Ruska vojaška doktrina iz leta 2010 še vedno predvideva, da bodo za vojaške konflikte značilne hitrost, visoka stopnja destruktivnosti, hitrost manevriranja z enotami in ognjeno močjo ter uporaba različnih visoko mobilnih sil. Za doseganje ciljev pa bodo odločilnega pomena strateška pobuda, stabilnost države in vojaškega sistema PINK ter zagotavljanje prevlade na kopnem, morju, v zraku in v vesolju (Ruska vojaška doktrina, 2010, t. 14).

Sodobni ruski vojaški teoretiki (npr. V. Slipchenko in V. Riabchuk) govorijo o vojskovanju šeste generacije, ki je nelinearno in nekontaktno (angl. noncontact) in katerega sestavni del so globoki udari s preciznim orožjem kot obliko prisile. Teorija nekontaktnega vojskovanja temelji na treh ciljih, ki jih je treba doseči, da bi zmagali v vojni: (1) uničiti sovražnikove oborožene sile (po pravilu na njegovem ozemlju); (2) uničiti sovražnikov ekonomski potencial; (3) zamenjati sovražnikov politični sistem (Slipchenko, 2005, str. 16). Če pogledamo vse tri cilje, je na prvi pogled jasno, da jih je mogoče doseči z zelo različnimi sredstvi, od konvencionalnega in nekonvencionalnega delovanja prek terorizma, informacijskega delovanja in vstajništva.

Žal ni dostopna ruska vojaška literatura, iz katere bi bilo razvidno, ali ruska vojska še naprej goji koncept združenega bojevanja rodov v obliki tako imenovane globoke bitke ali kako drugače. Je pa mogoče sklepati, da je združeno bojevanje rodov le del širše strategije hibridnega vojskovanja, ki ga, kot ugotavlja Schadlow, »/.../ Rusi obvladajo, Nato pa ne« (Schadlow, 2015, str. 3). Konflikt na Krimskem polotoku in njegova končna priključitev Ruski federaciji sta dokončno pokazala, da ruska vojaška miselnost ni več omejena z zamislimi konvencionalnega vojskovanja in da so ruska prizadevanja za modernizacijo oboroženih sil omogočila večje zmogljivosti za izvedbo dobro usklajenih specialnih operacij (Sinovets \& Renz, 2015, str. 7).

Združeno bojevanje rodov v ruski vojski ima nedvomno še vedno pomembno vlogo, vendar ne moremo oceniti, kako sposobna je v izvajanju kompleksnih operacij, ki bi združevale kopenske, mornariške in zračne enote $\mathrm{v}$ boju proti sposobnemu sovražniku (Sinovets \& Renz, 2015, str. 7). Predvsem pa menimo, da ga moramo razumeti v okviru teorije nekontaktne vojne.

Združeno bojevanje rodov ni nekaj novega niti ni omejeno na 20. in začetek 21. stoletja, temveč ga poznamo skozi vso zgodovino vojskovanja, le da so ga različne vojske različno uspešno uporabljale, skladno s tehnologijo, ki je bila na voljo. Če na primer pogledamo rimsko vojsko na višku imperija, lahko ugotovimo, da je šlo za vojsko, ki je v legiji združevala njegove elemente. Sovražnik, s katerim se je ta legija spopadla, je bil vsakokrat drugačen, od barbarskih plemen na vzhodnoevropskih 
mejah imperija, prek vstajnikov v današnji Palestini, do povsem konkurenčnih in enako profesionalnih vojsk v Perziji. Lahko bi celo rekli, da je bil hibriden.

House v svoji analizi združenega bojevanja rodov od začetka 20 stoletja in pojava vojsk industrijske dobe ugotavlja nekaj splošnih trendov v razvoju združenega bojevanja rodov (House, 1984, str. 188-190):

1. integracija vedno večjega števila rodov na vedno nižji organizacijski ravni, da bi uskladili zmogljivosti mobilnosti, ognjene moči in zaščite, ob tem pa bi te hkrati prestavljale bolj zapletene grožnje sovražnikovim enotam;

2. vsi rodovi in službe potrebujejo enako stopnjo mobilnosti in skoraj enako stopnjo oklepne zaščite, kot jo imajo enote, ki jih podpirajo;

3. rodovi znotraj organizacije morajo biti primerno uravnoteženi ${ }^{7}$, sestavljeni tako, da so učinkoviti glede na doktrino. Enote nad bataljonsko ravnjo, na kateri en rod številčno prevladuje nad drugimi, so lahko učinkovite v posebnih situacijah, vendar jim manjka fleksibilnosti. Podobno imajo tudi specializirani rodovi in elite vseh vrst posebne zmogljivosti, ki pa morajo biti uravnotežene z njihovimi ranljivostmi, ko jih ne podpirajo drugi rodovi;

4. vprašanje sodelovanja zračnih in kopenskih sil;

5. vprašanje sposobnosti in učinkovitosti obrambe različnih rodov in služb ob sovražnikovem prodoru.

Težnje po integraciji rodov na vedno nižji organizacijski ravni imajo seveda nekaj omejitev, zaradi katerih ni pričakovati združenega bojevanja rodov na ravni voda in oddelkov. Prva težava sta poveljevanje in kontrola. Združeno bojevanje rodov zahteva precej zapleten sistem PINK, ki ga enote brez štabov težko vzpostavijo. Druga velika težava pa je usposobljenost kadra za razmere združenega bojevanja rodov. Morda je tako še mogoče pričakovati bojno organiziranost na ravni čete, ki vključuje različne rodove, tako imenovane četne bojne skupine, a le v zelo omejenem obsegu. Na ravni poveljnika čete sicer že lahko pričakujemo ustrezno znanje in razumevanje vloge in naloge združenega bojevanja rodov (npr. četna bojna skupina, sestavljena iz dveh mehaniziranih in enega oklepnega voda ali kombinacija pehote in inženircev), na nižji ravni pa ne, saj se tu soočimo s težavo, ker ni ustrezno usposobljenega poveljniškega kadra. ${ }^{8}$ Kar seveda ne pomeni, da poveljnik voda ne more dobiti v podporo npr. artilerijske baterije.

House je analizo opravil leta 1984 in ugotovil, da so se ameriške zračne in kopenske sile po drugi svetovni vojni vedno znova morale učiti sodelovanja, ker tega v miru prej niso počele. Danes pa na podlagi dogajanja v vojnah po letu 1991 lahko ugotovimo, da je ta integracija na razmeroma visoki ravni in so vsaj v Natu razvite procedure in doktrine, ki so to težavo premagale.

\footnotetext{
Uravnoteženost pomeni, da imajo enote za manevrske elemente na voljo ustrezno število elementov ognjene podpore, inženirstva in drugih nujnih zmogljivosti rodov in služb.

$\&$ To izkušnjo so imeli v francoskih oboroženih silah (House, 1984, str. 170).
} 
House je izpostavil vprašanje obrambe različnih rodov, če pride do sovražnikovega prodora obrambnih linij. Ta težava je bila seveda kritična v okolju klasičnega vojskovanja, ko so bile frontne črte jasno opredeljene. V okolju hibridnega vojskovanja je ta težava lahko le še večja, saj je sovražnik hkrati povsod - pred nami, za nami, med nami, levo in desno.

\section{ZDRUŽENO BOJEVANJE RODOV V OKOLJU HIBRIDNEGA VOJSKOVANJA}

Vojna na ravni vojaka kljub vznesenim besedam o časti, pogumu in spopadu volj ostaja naporno, umazano in krvavo početje, kljub vsemu napredku v sodobni informacijski tehnologiji. Sovražnik, s katerim se danes soočamo, ni enoznačen, še manj so to izključno in samo oborožene sile, kot jih razumemo v zahodni civilizaciji.

V okoliščinah hibridnega vojskovanja temeljne predpostavke združenega bojevanja rodov postanejo še pomembnejše. Različne rodove in službe je treba integrirati na čim nižji organizacijski ravni, pri čemer pa je treba zagotoviti njihovo ustrezno uravnoteženost, le tako namreč lahko zagotovimo ustrezno odzivnost na najrazličnejše grožnje, v kateri bodo pomanjkljivosti enega rodu ali službe kompenzirane $\mathrm{z}$ zmogljivostmi druge.

Mobilnost in predvsem oklepna zaščita različnih rodov in služb morajo biti čim bolj izenačeni, saj se bo sovražnik v hibridnem vojskovanju nujno najprej osredotočil na najšibkejše člene.

Sodelovanje zračnih in kopenskih sil danes ni več tako problematično, so pa problematični veliki ubojni učinki sodobne oborožitve in z njimi povezana kolateralna škoda in njeno obvladovanje.

Če je House v začetku 80. let prejšnjega stoletja govoril o problemu obrambe različnih rodov in služb ob sovražnikovem prodoru, je ta problem v hibridnem vojskovanju samo še večji. Narava hibridnega vojskovanja predpostavlja, da ni več povsem jasnih linij spopadov, pač pa je sovražnik lahko kjer koli (informacijsko-kibernetsko delovanje, terorizem, vstajništvo). Sodelovanje rodov in služb v spopadu s tovrstnim sovražnikom je odločilnega pomena. Čeprav menimo, da sodobna informacijska tehnologija ni kaj dosti pripomogla k dvigu Clausewitzeve »megle vojne«, pa nam po drugi strani omogoča veliko učinkovitejše in odzivnejše združeno bojevanje rodov.

Danes morajo oborožene sile obvladovati združeno bojevanje rodov. To je prvi pogoj za zmago na bojišču. Ni pa dovolj za zmago v vojni. Za zmago v vojni, ki je politični, človeški in negotov spopad volj, mora biti združeno bojevanje rodov ustrezno nadgrajeno z informacijsko-kibernetskim delovanjem in hkratno uporabo vseh preostalih elementov nacionalne moči, kot sta gospodarsko in diplomatsko delovanje. To pa že presega okvire oboroženih sil in zahteva združeno bojevanje na višji ravni. 
V nadaljevanju bomo nekoliko natančneje pogledali, kako se sodobne vojske organizirajo za združeno bojevanje rodov in kaj vse bi to danes moralo obsegati. Pri tem smo za analizo uporabili taktične enote do ravni brigade vojsk ZDA, Velike Britanije in Ruske federacije, in sicer zaradi dveh vzrokov. Prvič, ker pomenijo temeljno referenco za vse sodobne vojske in so tudi zgodovinsko največ delale na konceptih združenega bojevanja rodov; drugič zato, ker je o njih na voljo največ odprtih referenčnih virov.

Danes je temeljna taktična enota Nata in Rusije ter Kitajske brigada. V tem smislu so vse sodobne vojske opustile divizijsko organiziranost kot osnovno obliko organiziranja za bojno delovanje in prešle na nižjo taktično raven brigade, katere poglavitni prednosti naj bi bili večja odzivnost in fleksibilnost. Če pogledamo formacije manevrskih brigad ZDA, Velike Britanije in Rusije (glej prilogo 1), vidimo uravnoteženost zmogljivosti za bojevanje, bojno podporo in zagotovitev delovanja. Brigada je načeloma sestavljena iz več (do pet) manevrskih elementov oziroma bataljonov, od katerih je vsaj eden izvidniški, več elementov bojne podpore različnih velikosti, a nikoli večjih od manevrskih elementov, ter elementa zagotovitve delovanja. Vse pa seveda povezujejo ustrezni elementi PINK.

Znotraj manevrskih elementov brigad oziroma bataljonov (glej prilogo 2) so ti uravnoteženi tako, da s svojimi zmogljivostmi zagotavljajo vse bojne funkcije ${ }^{9}$, brez velikih vrzeli v zmogljivostih in hkrati predpostavljajo sodelovanje različnih rodov (običajno oklepa in pehote).

Poleg združevanja pehote in oklepa kot temelja za izvedbo manevra vse tri vojske na ravni bataljonov poznajo izvidniške elemente ${ }^{10}$, element ognjene podpore v obliki minometov (120 $\mathrm{mm}$ ali 81/82 $\mathrm{mm}$ ), element protioklepnega boja (ki je nekoliko šibkejši v enotah, ki so opremljene s tanki - najboljše orožje za uničevanje tanka je pač tank), manjši element zagotovitve delovanja, ki bi načeloma moral omogočati samostojno delovanje ${ }^{11}$, in seveda element PINK s pripadajočimi zvezami, ki morajo v boju zagotavljati poveljevanje in kontrolo.

Zmogljivosti za zagotovitev bojnega delovanja so v vojski ZDA in ruskih oboroženih silah del brigade, medtem ko Britanci v svojih načrtih za vojsko do leta 2020 ne načrtujejo zmogljivosti za zagotovitev bojnega delovanja $\mathrm{v}$ manevrski brigadi. Vendar pa pregled njihovih strateških dokumentov pokaže, da vsaj v odzivnih silah načrtujejo ustrezne elemente zagotovitve bojnega delovanja. Tako načrtujejo v logistični brigadi za vsako logistično zmogljivost po en element, ki bi ustrezal potrebam ene manevrske brigade, 16. zračnojurišna brigada (angl. Air Assault) pa ima povsem lastne elemente zagotovitve bojnega delovanja (Transforming the British Army, 2013, str. 7). Nekoliko drugače je z načrtovanimi prilagodljivimi

\footnotetext{
9 Pri tem sem upošteval bojne funkcije, kot jih opredeljuje zavezništvo in ne doktrina SV.

${ }^{10}$ Torej poleg obveščevalno-izvidniškega elementa v velikosti $B N(+)$ na ravni brigade najdemo tudi razmeroma močan izvidniški element na ravni bataljona. Pridobivanje informacij je pač ključnega pomena za uspeh v boju.

"Dolžina je odvisna od doktrine posameznih oboroženih sil, giblje pa se okoli 72 ur.
} 
silami (angl. Adaptable Force), v katerih načrtujejo za sedem manevrskih brigad eno logistično brigado (Transforming the British Army, 2013, str. 3). Tako za odzivne kot za prilagodljive sile pa bodo zmogljivosti artilerije, inženirstva, zvez, sanitete, obveščevalno-izvidniške in vojaške policije prihajale iz tretje skupine sil, v kateri so združene pod enotnim poveljstvom (Transforming the British Army, 2013, str. 12-13). Britanske oborožene sile torej načrtujejo odmikanje od načela integriranosti rodov in služb na taktični ravni brigade in zanimivo bo videti, kakšne bodo njihove izkušnje. Še vedno pa je brigada za Britance temeljna taktična enota za bojevanje.

Danes se v zmogljivostih brigadne ravni ravno zaradi hibridne narave sovražnika pojavljajo tudi nekatere nove zmogljivosti, ki pa niso nujno razvidne iz organizacijske strukture enot na brigadni ravni. To je prepoznalo tudi zavezništvo, ki te zmogljivosti predpostavlja v manevrskih brigadah, čeprav niso nujno samostojne organizacijske enote. To so zmogljivosti civilno-vojaškega sodelovanja (CIMIC), psihološkega delovanja (PSYOPS) in EOD, v zadnjem času pa tudi zmogljivosti kibernetskega delovanja.

Vse tri vojske dajejo precej pomena ustreznim izvidniško-obveščevalnim zmogljivostim na ravni brigade. Povsod namreč najdemo izvidniški bataljon in obveščevalno-izvidniško četo na ravni brigade. To je v kontekstu sodobnega informacijskega bojevanja tudi razumljivo. Informacije so bile vedno ključ do uspeha, tudi na sodobnem bojišču, na katerem smo soočeni z najrazličnejšimi oblikami delovanja in poplavo informacij, kar zahteva ustrezne zmogljivosti.

Predvsem pa so brigade in bataljoni primerno uravnoteženi po posameznih rodovih in službah. Tako imajo brigade dovolj artilerijskih zmogljivosti, da lahko hkrati podpirajo vse manevrske enote v sestavi. Enako velja tudi za druge rodove in službe. Kjer imamo na brigadni ravni zmogljivost rodu ali službe v rangu čete ali nižje, se ta naj ne bi delila na manevrske elemente, kar pa na primer za brigado SV ne drži, saj je v njej le ena artilerijska baterija za dva pehotna polka.

\section{SLOVENSKA VOJSKA IN ZDRUŽENO BOJEVANJE RODOV}

Vse večje vojske v Evropi so že pred časom prešle z divizijskega načela organizacije za bojevanje na brigadnega.

Menimo, da je SV s transformacijo v letih 2012/2013 naredila velike korake v pravi smeri. Predvsem je transformacija SV poskrbela za integracijo rodov na taktični ravni brigade in menimo, da je prinesla precej pozitivnega tudi na področju združene ognjene podpore. (Pišlar, 2013, str. 9-12) Moram pa ugotoviti, da transformacija s stališča združenega bojevanja rodov ni rešila težav ustrezne uravnoteženosti rodov in služb, ustrezne mobilnosti in zaščite ter obrambe ob prodoru.

Polki SV niso sposobni za samostojno bojevanje zunaj brigade oziroma celotne Slovenske vojske. Iz trenutno veljavnega SOPR 2013-2018 ni povsem jasno, ali so 
sploh namenjeni samostojnemu delovanju. ${ }^{12}$ Kolikor pa je javno dostopnih virov o organizaciji in strukturi polkov SV, pa lahko ugotovimo, da imajo s stališča bojnih funkcij $^{13}$ velike omejitve praktično na vseh bojnih funkcijah. Pehotni polki SV ne morejo delovati samostojno. ${ }^{14}$ Lahko delujejo le kot del bataljonske bojne skupine (BBSk), ki jo zaradi mankov na ravni brigadne logistike lahko sestavi le celotna SV. Hkrati pa oblikovanje BBSk za brigado pomeni, da so preostale enote nesposobne smiselnega bojnega delovanja in je s tem brigada nesposobna zanj. Podobno so ugotavljali tudi Rusi na višji taktični ravni divizije, sestavljene iz polkov (Herspring v Blank in Weitz, 2010, str. 165) ${ }^{15}$. Le če bi brigada SV delovala kot celota, to je kot bojna skupina, bi lahko prišle do izraza vse njene prednosti, pa še to je vprašljivo zaradi odsotnosti elementov zagotovitve bojnega delovanja, pri čemer tudi logistična brigada nima primerne modularne strukture, da bi hitro in nezapleteno sestavljala primerne module za zagotovitev bojnega delovanja (kot npr. to načrtuje britanska vojska). Na brigadni ravni SV tako:

- ni ustreznih izvidniških zmogljivosti, kar je nesprejemljivo v dobi informacijskega vojskovanja;

- ni ustrezne zmogljivosti ognjene podpore;

- ni skoraj nikakršnih zmogljivosti zagotovitve bojnega delovanja;

- na polkovni ravni pa ni ustreznih zmogljivosti za bojevanje (ni minometov, protioklepa, zvez in predvsem ni ustrezne logistike za delovanje).

Ima pa zdaj brigada SV zmogljivosti inženirstva, obveščevalno-izvidniške zmogljivosti, zmogljivosti zvez in protioklepa ${ }^{16}$, ki jih prej ni imela.

Ob tem se zastavlja tudi vprašanje smiselnosti čete jedrske, radiološke, kemične in biološke obrambe (JRKBO) in čete vojaške policije (VP) na ravni brigade. Vsekakor je to ena izmed mogočih rešitev, ki ni nujno slaba. Rešitev ni napačna, konec koncev jo pozna na ravni brigade tudi ruska vojska (glej prilogo 1), manjše elemente JRKBO pa ima v sestavi tudi brigada ZDA.

Brigada SV izkazuje izrazito neuravnoteženost zmogljivosti za združeno bojevanje rodov. Številčno je v njej preveč klasične pehote, ki pa na polkovni in brigadni ravni nima dovolj zmogljivosti za kompenziranje svojih pomanjkljivosti v ognjeni moči, mobilnosti in zaščiti, niti nima dovolj zmogljivosti za zagotovitev delovanja (vsaj

\footnotetext{
${ }_{12}$ Žal so dokumenti, ki opredeljujejo poslanstvo in glavne naloge pehotnih polkov, zaupne narave, zato teh informacij $v$ tem besedilu ne morem navajati.

${ }^{13}$ Pri tem so bojne funcije kot jih navaja doktrina SV metodološko nekoliko zastarele in sem v analizi zato uporabljal bojne funkcije, kot jih opredeljuje zavezništvo: manever in ognji, obveščevalne zadeve, zagotovitev delovanja, zaščita sil, poveljevanje in kontrola ter civilno-vojaško sodelovanje in informacijske operacije (AJP01(D) Alied Joint Doctrine, 2011, str. 5-2 in 5-3).

14 Vprašanje pa je, ali naj bi pehotni polki SV sploh bili namenjeni samostojnemu delovanju ali predstavljajo le »bazen« za oblikovanje bataljonskih bojnih skupin. Mnenja so deljena, dejstvo pa je, da nimajo nikakršnih zmogljivosti ognjene podpore, $v$ vseh drugih zmogljivostih (z izjemo pehotnih) pa so zelo omejeni (izvidniki, protioklep, zagotovitev delovanja, zveze itn.).

${ }^{15}$ Vojna v Gruziji leta 2008 je pokazala, da je divizija kot taka preokorna in prevelika enota za sodobno bojevanje. Večino teže bojev v Gruziji so nosili polki iz sestavov divizij, ki pa samostojno niso bili sposobni delovati, temveč je morala divizija oblikovati tako imenovane polkovne bojne skupine iz vseh svojih enot, kar je hkrati pomenilo, da divizija kot taka ni bila več sposobna delovanja.

${ }^{16}$ Protioklep ima brigada na račun odsotnosti protioklepa na polkovni ravni.
} 
72-urna samostojnost). Prav tako nismo ustrezno rešili zagotovitve bojnega delovanja s konceptom logistične brigade, kar kažejo nenehne težave pri oblikovanju BBSk. ${ }^{17}$

Vprašanje mobilnosti in zaščite ni veliko vprašanje le v SV, temveč v vseh sodobnih vojskah. Ključ za njihovo reševanje so predvsem finančna sredstva, ki so izjemno omejena. Oklep v kateri koli obliki veliko stane. Oklepna sredstva SV pa so z izjemo dveh čet SKOV že razmeroma stara oziroma že zastarela. To pa niti ni največja težava. Z ustreznim vzdrževanjem se življenjski cikel sredstev lahko podaljša, čeprav veliko različnih tipov tehničnih sredstev prinaša posebne izzive pri vzdrževanju. Večja težava je, da so tudi sredstva, ki so na voljo, nezadostna, predvsem pa neenotna. Bistvena je tu težava zaradi neenotnosti in s tem povezljivosti sredstev PINK.

SV je v zadnji letih naredila velike korake v smeri zračno-kopenske integracije. Usmerjevalci združenega ognja (angl. JTAC) so nosilci te integracije. Upoštevanje ustreznih zavezniških standardov na tem področju uspešno rešuje pretekle dileme zračno-kopenske integracije, vendar čaka SV še veliko dela na področju združenega bojevanja rodov, predvsem pri integraciji artilerije v zračno-kopensko delovanje. Usmerjevalci posredne ognjene podpore (angl. JFO), ki so tesno povezani z artilerijskimi izvidniki, so ena mogočih poti do integracije artilerije v združeno bojevanje rodov.

Seveda pa je ključ do celotnega sistema v rokah sistema PINK in sodobnih informacijskih tehnologij. Tu mora SV storiti največ in najtežje korake. Trenutni sistem IS PINK ne omogoča ustrezne ravni združenega bojevanja rodov, saj ne omogoča omrežnega delovanja manevra, artilerije in zračne podpore, prav tako ne vključevanja preostalih rodov in služb v to omrežno delovanje. Kibernetsko delovanje je posebno poglavje, ki precej presega zmožnosti tega članka, ga je pa nujno upoštevati pri sodobnem združenem bojevanju rodov.

\section{Ugotovitve, relevantne za SV}

Združeno bojevanje rodov ima svoje mesto tudi v okoliščinah sodobnega hibridnega vojskovanja. Še več, menimo, da je ob hibridnih grožnjah obvladovanje načel združenega bojevanja rodov pomembnejše, kot je bilo kadar koli prej. Tudi trendi, ki jih je že leta 1984 opredelil House, so še vedno pomembni in upoštevanja vredni. Predvsem iskanje odgovora na vprašanje sovražnikovega prodora, ki je po avtorjevem mnenju v sami naravi hibridnega vojskovanja, je še kako pomembno tudi danes.

Dejstvo je tudi, da je združeno bojevanje rodov celovit in vsestranski proces, ki potrebuje ustrezen poveljniški element. Kot vidimo, sodobne vojske gojijo združeno bojevanje rodov predvsem na brigadni ravni, posamezne elemente pa tudi na nižjih, a ne nižje od čete.

${ }_{17}$ Težave so jasno razvidne iz zapisnikov preverjanj in nadzorov v BBSk, ki so navedeni med viri. 
Pri oblikovanju enot je treba posebno pozornost nameniti prav uravnoteženosti različnih rodov in služb, da se prednosti in ranljivosti posameznih zmogljivosti lahko ustrezno dopolnjujejo.

Pri zaščiti ter mobilnosti se je treba zavedati, da je enota zaščitena in mobilna le toliko, kot je zaščiten in mobilen njen najšibkejši člen.

Za uspešnost koncepta združenega bojevanja rodov pa niso najpomembnejše uravnoteženost, zaščita, mobilnost ali celo rešitev vprašanja usklajevanja in obrambe ob prodoru. Za združeno bojevanje rodov je bistvena integracija, ki pomeni skupno usposabljanje vseh rodov in služb. S transformacijo leta 2012 in združevanjem rodov ter služb na brigadni ravni je SV na tem področju zanesljivo naredila korake v pravo smer.

Zaradi kadrovskih in finančnih omejitev mora Slovenska vojska iskati primerne rešitve. Brigada bi morala nedvomno tudi v SV ostati temeljna taktična enota za združeno bojevanje rodov in nadaljnji razvoj doktrine bojevanja. To pa ne pomeni, da mora imeti vse elemente zmogljivosti, kot jih poznamo drugod, ali da bi jih morala imeti $\mathrm{v}$ enakem obsegu. Kot je pokazala analiza, tega nimajo niti Britanci. Poleg tega SV ne predvideva delovanja brigadne bojne skupine znotraj zavezništva, ampak le za obrambo nacionalnega ozemlja (ReDPROSV2025, 2011, str. 31). To še zdaleč ne sme in ne more pomeniti, da se doma bojujemo na drugačnih doktrinarnih temeljih kot v zavezništvu. Doktrina mora biti ena sama, sicer je zmeda popolna. Ker pa brigada ni sila, premestljiva na ozemlje zunaj RS, je njen logistični podpis lahko v primerjavi s primeri, navedenimi zgoraj, ustrezno manjši. Hkrati je lahko njen izvidniški element prilagojen potrebam delovanja zgolj na nacionalnem ozemlju.

Kljub vsemu pa je za uspešnost koncepta združenega bojevanja rodov nujno, tako $\mathrm{v}$ polkih kot pehotni brigadi, bolje uravnotežiti in integrirati rodove in službe po bojnih funkcijah ${ }^{18}$.

$\mathrm{Na}$ račun številčnosti pehote je treba povečati zmogljivosti ognjene podpore in protioklepnega boja, tako na polkovni kot na brigadni ravni. Pri tem bi veljalo razmisliti ne le o povečanju zmogljivosti protioklepnega orožja, temveč tudi o oklepni četi v vsaj enem izmed polkov SV. Na polkovni ravni je nujna ponovna uvedba minometov ${ }^{19}$, prav tako je nujno povečati zmogljivosti za protioklepni boj na polkovni ravni ter zagotoviti polkovno sposobnost 72-urnega samostojnega delovanja.

Na brigadni ravni je zmogljivost ognjene podpore izjemno omejena, zato bi veljalo razmisliti o ponovni vzpostaviti dveh artilerijskih bataljonov ali divizionov (po enega v vsaki brigadi) oziroma o minimalni okrepitvi baterije za ognjeno podporo (BATOP) z dveh vodov vsaj na štiri (glej prilogo 3-V1/V2/V3).

\footnotetext{
18 Bojne funkcije kot jih opredeljuje Nato.

${ }^{19}$ Ne le na četni ravni, temveč tudi polkovni.
} 
Absolutno nujna je ustrezna izvidniška zmogljivost na ravni brigade in njeno povečanje tudi na polkovni ravni. V okolju hibridne grožnje in informacijskega vojskovanja je pridobivanje informacij o sovražniku bistvenega pomena. Mogoča inačica organiziranosti bi bila, da ob dveh pehotnih polkih v brigadi vzpostavimo še dva pehotna polka in en izvidniški polk vojaške strateške rezerve (VSR). Hkrati je treba okrepiti tudi analitične in senzorske zmogljivosti na brigadni ravni za boljše obvladovanje informacij na bojišču. Pri tem smo upoštevali, da se brigada SV za bojno delovanje oblikuje samo za delovanje v domovini, kar pa po mnenju avtorja tega članka pomeni aktiviranje elementov vojaške strateške rezerve. S strateško rezervo bi lahko vzpostavili potrebne dodatne manevrske polke ali bataljone in izvidniške zmogljivosti za delovanje brigade SV na nacionalnem ozemlju. Brigada SV bi tako pridobila na izvidniških zmogljivostih, pri čemer pa ne bi bila v ničemer zmanjšana njena sposobnost oblikovanja motorizirane oziroma mehanizirane BBSk. Brigada bi tako lahko sestavila BBSk z oblikovanjem poveljstva nosilnega polka, uravnoteženo sestavo manevrskih čet ter zmogljivostmi rodovskih enot brigadne ravni. Dodatno bi veljalo razmisliti tudi o inženirskih zmogljivostih na ravni brigade. Te morajo zagotavljati tako zmogljivosti bojnega inženirstva kot omejene gradbene in mostovne zmogljivosti. ${ }^{20}$ Morebitna struktura take brigade je opredeljena v prilogi 3/V2.

Struktura vojaške strateške rezerve znotraj brigade bi tej omogočila mirnodobno usposabljanje poveljstva brigade iz združenega bojevanja rodov na brigadni ravni, saj bi tako imela ustrezne izvidniške in manevrske zmogljivosti za delovanje na polovici nacionalnega ozemlja. Seveda pa bi bilo treba uporabnost strukture take brigade za delovanje na nacionalnem ozemlju preveriti z računalniško podprtimi štabnimi simulacijami.

Treba bi bilo razmisliti o smiselnosti zadrževanja prostovoljne pogodbene rezervne sestave (PPRS) na polkovni ravni (ena četa). Polki so jedro za oblikovanje BBSk, ki je v bistvu namenjena delovanju v zavezništvu (ReDPROSV2025, 2011, str. 31). S PPRS si v tem pogledu in glede na sedanje zakonske delovnopravne rešitve težko zares pomagamo. Po drugi strani pa je PPRS namenjena prav dopolnjevanju enot stalne sestave v vojni ali vojni nevarnosti. Kot že zapisano, pa so brigadne bojne skupine namenjene ravno delovanju v obrambi nacionalnega ozemlja. Tako bi imelo popolnjevanje enot ravni pehotne brigade in logistične brigade s pripadniki PPRS več smisla. Od stalne sestave bi se na brigadni ravni zadržalo le toliko kadra, kot je nujno za oblikovaje BBSk in izpolnjevanje drugih zavez do zavezništva.

$\mathrm{S}$ stališča omejenosti virov je seveda treba iskati primernejše rešitve za vprašanje zagotovitve bojnega delovanja in delovanja SV. Morda bi lahko kombinirali britanske in ameriške rešitve, in sicer tako, da bi vzpostavili ločene zmogljivosti za

\footnotetext{
${ }^{20}$ Gradbene zmogljivosti morajo omogočati omejene zmogljivosti utrjevanja, mostovne zmogljivosti pa premagovanje manjših linijskih ovir (kanalov).
} 
zagotovitev bojnega delovanja in ločene za zagotovitev delovanja SV kot celote ${ }^{21}$. Zato bi morali v manevrskih brigadah za zagotovitev bojnega delovanja oblikovati v vsaki po eno zdravstveno četo, četo za vzdrževanje in četo za oskrbo. Za potrebe polkov pa v vsaki brigadi do šest ${ }^{22}$ čet za prednjo logistično oskrbo. Mogoče bi to lahko zmanjšali na pol $^{23}$ oziroma bi polovico teh enot popolnili s PPRS.

Zmogljivosti vojaške policije bi morali izločiti iz sestave pehotne brigade in iz njih ter $\mathrm{SEVP}^{24}$ oblikovati dve specializirani četi vojaške policije, ker smo se tako zavezali zavezništvu, in jih zadržati na operativno-strateški ravni.

Četudi ne oblikujemo samostojnega JRKBO-bataljona in zadržimo čete JRKBO na brigadni ravni in druge zmogljivosti v SV, pa je nujno oblikovanje ogrodja bataljona JRKBO (zavezništvo uporablja izraz FRWK BJRKBO) zaradi izpolnjevanje zavez do zavezništva.

Ključno pa je seveda zagotoviti preostale elemente zagotovitve delovanja in PINK na taktični ter operativno-strateški ravni.

Ena izmed mogočih variant, ki pa ni optimalna, je tudi oblikovanje zgolj ene manevrske brigade. Tako bi se sprostili precejšni kadrovski potenciali na taktični ravni, ki bi jih lahko uporabili drugje, in bi s sedanjo stalno sestavo brez večjih težav oblikovali sodobno in primerno opremljeno manevrsko brigado. Struktura take brigade je predstavljana $\mathrm{v}$ prilogi 3/V3.

Vendar menimo, da ena sama manevrska brigada ne more izpolniti poslanstva SV pri nacionalni obrambi (čemur je doktrinarno namenjena), četudi jo podpre celotna vojaška strateška rezerva. Kljub pregovorni majhnosti državnega ozemlja je to kljub vsemu precej preveliko, predvsem pa topografsko preveč razgibano za zmogljivosti ene same brigade ${ }^{25}$. Enobrigadna struktura pa s seboj prinaša še vrsto drugih težav, zato menimo, da ena brigada pomeni de facto konec nacionalne vojske in konec možnosti uveljavljanja koncepta vojaške strateške rezerve ${ }^{26}$. Ob tem se nam zastavlja še vrsta drugih vprašanj v varianti enobrigadne strukture, kot so razvoj profesionalizma v SV, vprašanje zdrave kadrovske politike, možnost združevanja STAS, PPRS in VSR na brigadni ravni, obstoj zdrave tekmovalnosti med dvema brigadnima poveljniškima skupinama, vprašanje rodovske vertikale in tekmovalnosti, obstoj operativnih ciklov, možnost hkratnega oblikovanja dveh BBSk za obrambo nacionalnega ozemlja v okviru zavezništva. Do vseh teh pa se avtor težko opredeli,

\footnotetext{
${ }^{21}$ Torej v okviru logistične brigade vzpostaviti ločene prostorske zmogljivosti za delovanje celotne SV, $v$ manevrskih brigadah pa zmogljivosti bojne logistike za brigade.

${ }^{22}$ Po ena četa na pehotni bataljon/polk, ena na artilerijski bataljon in ena za izvidniški bataljon/polk.

${ }^{23}$ Druga polovica pa bi predvidevala strateško rezervo.

${ }^{24}$ Specializirana enota vojaške policije.

${ }_{25}$ Seveda se zastavlja vprašanje, ali sta za obrambo nacionalnega ozemlja dovolj že dve manevrski brigadi. Domneva avtorja je, da sta. Ob predpostavki, da sta aktivirani PPRS in strateška rezerva ter da SV deluje v okviru zavezništva.

${ }^{26}$ Glede omejitev veljavnega koncepta VSR je avtor pisal v svojem prejšnjem članku o obsegu in naravi SV.
} 
saj presegajo okvir njegovega védenja. Do njih bi se morala s strokovno razpravo opredeliti vojaška stroka.

Menimo, da bi predlagane spremembe v variantah 1 in 2 pomenile kvečjemu zelo minimalno številčno povečanje SV na taktični ravni ${ }^{27}$. Ker ločene operativne ravni praktično ni več, je to mogoče le z zmanjševanjem moštva na strateško-operativni ravni in $\mathrm{v}$ tako imenovanem institucionalnem, a vojaško nerelevantnem delu vojske (orkester, športna enota, protokol, uradniki, civilne osebe itn.). To pa seveda pomeni hkratno reorganizacijo obrambnega sistema na ravni $\mathrm{MO}$, v katerem so še vedno vsi elementi splošne ljudske obrambe in družbene samozaščite, ter oblikovanje modernega obrambnega štaba, o čemer pa bi bila nujna širša strokovna razprava znotraj resne politične pripravljenosti za spremembe.

Slovenska vojska mora za učinkovito obvladovanje koncepta združenega bojevanja rodov storiti še kar nekaj velikih korakov. Združeno bojevanje rodov je tudi na sodobnem vojskovališču nujen pogoj za uspeh, le da danes njegovi učinki segajo tudi v informacijsko-kibernetski prostor, kar je povzročilo, da je koncept še bolj zapleten in težje obvladljiv. Slovenska vojska tu zaostaja za modernimi trendi. Vendar to ni le njena težava, temveč celotnega obrambnega sistema. Bojevanje v okolju hibridnega vojskovanja ni in ne sme biti le zadeva oboroženih sil, temveč je po svoji naravi stvar celotnega obrambno-varnostnega sistema države. Slovenska vojska se s konceptom združenega bojevanja rodov s sovražnikom na hibridnem vojskovališču uspešno spopade, sama pa v vojni z njim ne more zmagati, in sicer zato, ker je za zmago v vojni s sovražnikom na hibridnem vojskovališču nujno učinkovito delovanje $\mathrm{v}$ informacijsko-kibernetskem prostoru in spopadanje z izvorom sovražnika, česar pa praktično nobena vojska na svetu ne zmore sama, ne le slovenska. Združeno bojevanje rodov je koncept, ki omogoči premagovanje sovražnika na hibridnem vojskovališču v neposrednem boju, pri čemer poskrbi za ustrezno zaščito lastnih sil. Za zmago v vojni z njim pa je treba veliko več.

\footnotetext{
${ }^{27}$ Izračuni, ki jih je avtor opravil, sicer kažejo, da bi po predlogu 2. variante obseg ene brigade SV (brez logističnega elementa) znašal od 1800 do 1950 pripadnikov STAS in PPRS. To je sicer manj, kot je trenutni obseg STAS in PPRS v pehotnih brigadah. Treba pa je vedeti, da trenutni pehotni polk SV šteje približno 700PAX in da je predlagani manevrski bataljon oziroma polk za več kot eno četo manjši. Poleg tega je predlagana oklepna četa kadrovsko precej manjša od pehotne. Kadrovski prihranki bi se tako lahko prelili $v$ povečanje zmogljivosti preostalih rodov, predvsem artilerije in inženirstva. Poleg tega vse predlagane variante izključujejo zmogljivost JRKBO in VP iz sestave pehotne brigade SV.
} 
Priloga 1:

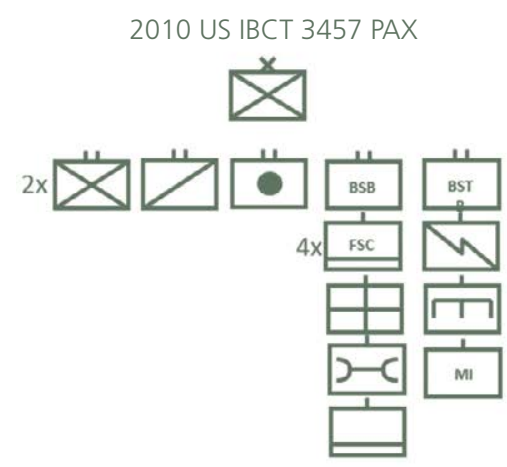

2020 UK-brigada meh. pehote cca. 5000 PAX

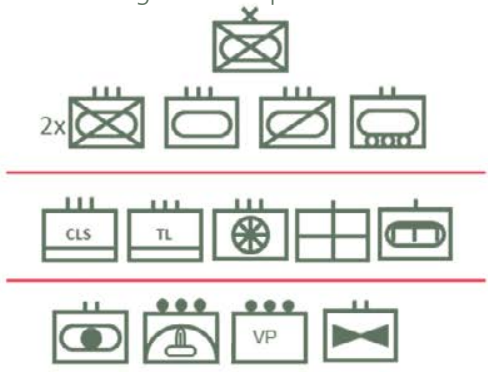

2009 Ruska "New Look" brigada cca. 4300 PAX

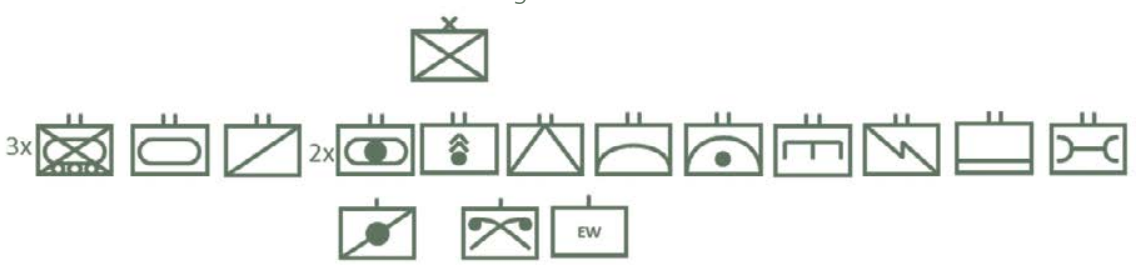

Priloga 2:

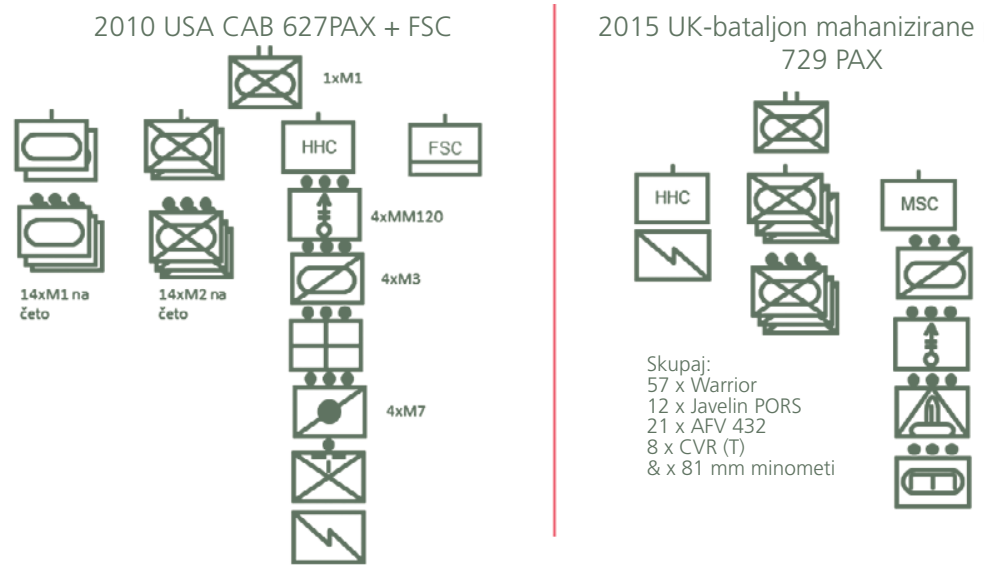

2009 Ruski moto-strelski bataljon 510 PAX

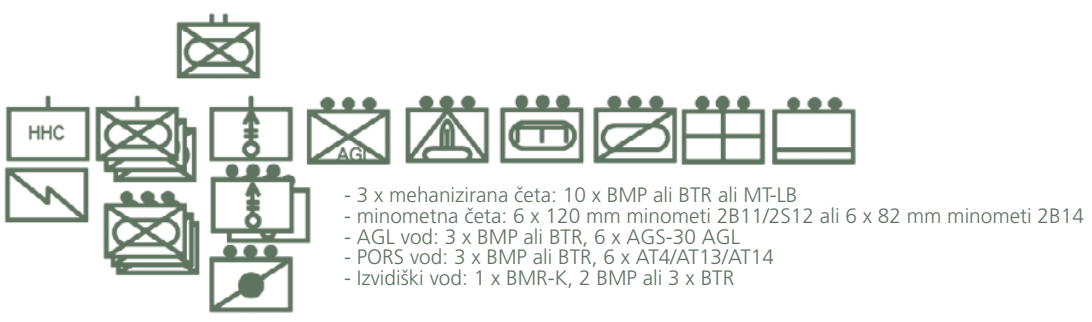


Priloga 3:

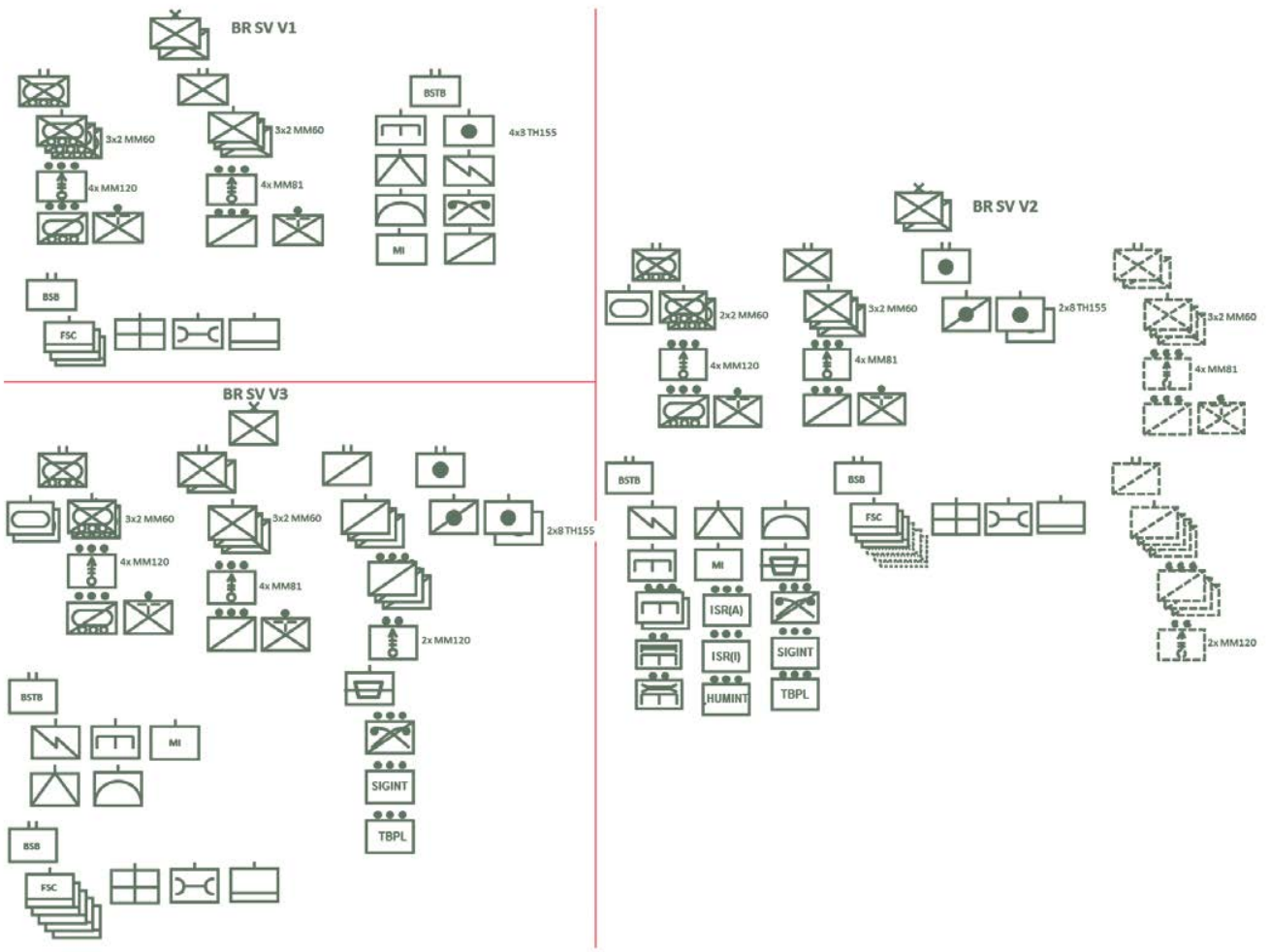

Razlaga simbolov:
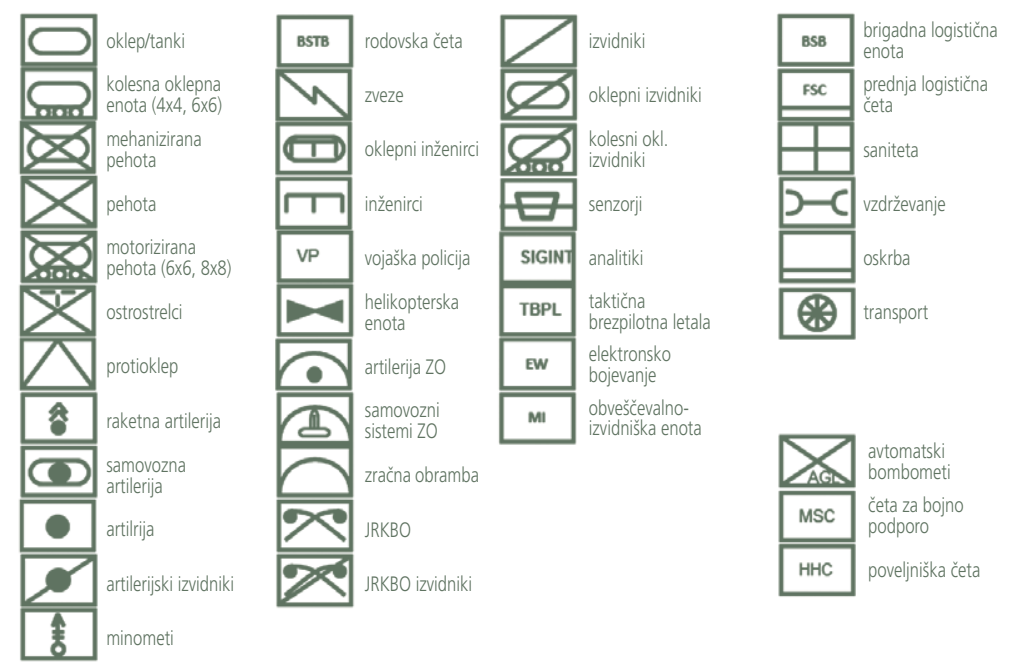

$\times$ brigada

III polk

II batalion

1 čta

$\bullet \bullet \operatorname{vod}$

- skupina

- oddelek 


\section{Literatura}

1. Barabanov, M., 2011. Russia's New Army. Centre for Analysis of Strategies and Technologies, Moscow, Russia.

2. Blank, S. J., in Weitz, R., 2010. The Russian Military Today and Tomorrow: Essays in memory of Mary Fitzgerald. U.S. Army War College, Strategic Studies institute.

3. Brinc in drugi, 2006. Angleško-Slovenski vojaški terminološki slovar. PDRIU http://intra. mors.si/index.php?id=1718 (13. 6. 2015).

4. British Army, 2010. ADP-Operations. Army Publications Team, Andower.

5. British Army, 2013. Transforming the British Army - an update. Army Headquarters.

6. Državni zbor RS, 2010. Resolucija o strategiji nacionalne varnosti Republike Slovenije (ReSVN-1). Ljubljana: MO RS.

7. Državni zbor RS, 2010. Resolucija o splošnem dolgoročnem programu razvoja in opremljanja Slovenske vojske do leta 2025 (ReSDPRO SV 2025). Ljubljana: MO RS.

8. FKSM 71-8, 2010. Armor/Cavalry reference data; Brigade combat teams. US Army Armor Center, Fort Knox, KY.

9. Furlan, B. (in drugi), 2006. Vojaška doktrina. Ljubljana: Defensor, d. o. o.

10. FM 100-2-1, 1984. The Soviet Army: Operations and Tactics. Washington D.C., Headquarters of the Army.

11. Garb in drugi, 2009. Razlagalni vojaški slovar. http://intra.mors.si/index.php?id=1718 (13. 6. 2015).

12. Gareev, M., in Slipchenko, V., 2005. Future War. Moscow, Obedinennoye Gumanitarnoye Izdatelstvo.

13. House, J. M., 1984. Toward Combined Arms Warfare: A survey of $20^{\text {th }}$ century tactics, doctrine and organization. Combat Studies Institute Press, Fort Leavenworth, Kansas.

14. McMaster, H. R., 2015. Continuity and Change; The army operating concept and clear thinking about future war. Military Review.

15. NATO, 2010. AJP-01(D) Alied Joint Doctrine. NATO Stardandisation Agency.

16. NATO, 2013. AAP-06 Edition 2013, NATO glossary of terms and definitions (English and French). NATO Stardandisation Agency.

17. NATO, 2009. AJP-3.2 Alied Joint Doctrine for Land Operations. NATO Stardandisation Agency.

18. NATO, 2009. ATP-3.2.1 Alied Land Tactics. NATO Stardandisation Agency.

19. National Defence-Army, 2011. Battle Group in Operations. Canada Chief of the Land Staff.

20. Pickar, C. K., 1991. Tactical deep battle: the missing link. School of Advanced Military Studies - monograph, USA CGSC, Fort Leavenworth, Kansas.

21. Pišlar, M., 2013. Okrogla miza o osrednji vojaški vaji SV Premik 2013. MO RS, Revija Slovenska vojska, Ljubljana.

22. Poročilo o izvedenem skupinskem nadzoru v 1. BR. Številka: 060-82/2015-3, z dne 8. 6. 2015.

23. Puyvelde, D., 2015. Hybrid war-does it even exist?. Nato Review.

24. Schadlow, N., 2015. The problem with Hybrid warfare. Smith Richardson Fundation.

25. Sinovets, P., \& Renz, B., 2015. Russia's 2014 Military Doctrine and beyond: threat perceptions, capabilities and ambitions. NATO Defense College, Rome.

26. Student text 100-3, 2007/2008. Battle Book. USA CGSC, Fort Leavenworth, Kansas.

27. Škerbinc, M., 2015. Hibridno vojskovanje. Revija Obramba. Maj 2015.

28. Thornton, R.. 2011. Military Modernization and the Russina Ground Forces. U.S. Army War College, Strategic Studies Institute.

29. Vlada RS, 2013. Srednjeročni obrambni program Republike Slovenije 2013-2018. Ljubljana: št. 80300-1/2013/3 z dne 1. 2. 2013. 
30. Zapisnik, 2015. Dogodek: Analiza ZOZ MotBBSk, 18. 5. 2015 ob 12.30 voperativni sobi POV 1. BR, št. 803-3/2015-133 z dne 21. 5. 2015

31. Strategy Page, Armor Discussion Board, Subject:New Russian Brigades TOE, http://www. strategypage.com/militaryforums/2-21230.aspx\#startofcomments (23. 6. 2015).

32. Strategy Page, Armor Discussion Board, Subject:New Russian Brigades TOE, http://www. strategypage.com/militaryforums/2-21230.aspx\#startofcomments (23. 6. 2015).

33. The British Army, Formations, ARMOURED INFANTRY BRIGADE ORGANISATION http://www.armedforces.co.uk/army/listings/l0013.html (23. 6. 2015).

34. The British Army, Formations, BATTLEGROUPS AND COMPANY GROUPS/TASK GROUP http://www.armedforces.co.uk/army/listings/l0014.html (23. 6. 2015).

35. The British Army, Formations, ARMOURED INFANTRY BATTALION http://www. armedforces.co.uk/army/listings/l0033.html (23 .6. 2015).

36. The British Army, Formations, HEAVY PROTECTED MOBILITY BATTALION http:// www.armedforces.co.uk/army/listings/l0030.html (23. 6. 2015).

37. The British Army, Formations, LIGHT PROTECTED MOBILITY BATTALION http:// www.armedforces.co.uk/army/listings/l0031.html (23. 6. 2015). 